\title{
Kinerja pegawai pada Biro Pengadaan Barang dan Jasa Sekretariat Daerah Provinsi Kalimatan Tengah
}

\section{Employee performance analysis at the Bureau of Public Procurement, Regional Secretariat of Central Kalimantan Province}

\author{
Edwin Adipratama ${ }^{1,}{ }^{*}$, Ferdinand $^{2}$, Fitria Husnatarina ${ }^{2}$ \\ ${ }^{1}$ Dinas Perdagangan dan Perindustrian Provinsi Kalimantan Tengah \\ ${ }^{2}$ Program Studi Magister Manajemen Program Pascasarjana Universitas Palangka Raya \\ * Korespondensi: Edwin Adipratama (Email: edwinadipratama@gmail.com)
}

\begin{abstract}
Government procurement of goods and services is one of the important driver in spurring economic growth at both the national and regional levels. Efficient and effective government procurement of goods and services is an important part of achieving performance in an organization. The success of an organization is largely determined by performance, which means that performance is carrying out an activity and making improvements according to responsibility with the expected results. Performance is an effort from a goal depending on the results of the activities achieved. This study aims to analyze the influence of competency on employee performance through work motivation as an intervening variable in the Procurement Bureau of the Regional Secretariat of Central Kalimantan Province. The method used in this research is explanation. Data were analyzed using descriptive analysis and inferential statistical analysis of the Structural Equation Modeling (SEM) model using the Partial Least Square (PLS) approach and validity and reliability tests. The results of the study concluded that competency has no direct effect on performance, competency has a direct effect on motivation, work motivation has a direct effect on performance. The motivation variable is an intervening variable, the relationship between competency and performance.
\end{abstract}

\section{Keywords}

Competency, work motivation, performance

\section{Intisari}

Pengadaan barang dan jasa pemerintah merupakan salah satu penggerak penting dalam memacu pertumbuhan ekonomi baik di tingkat nasional maupun daerah. Pengadaan barang dan jasa pemerintah yang efisien dan efektif merupakan salah satu bagian yang penting dalam pencapaian kinerja dalam suatu organisasi. Kesuksesan suatu organisasi sangat ditentukan oleh kinerja, yang mana dalam artinya kinerja adalah melakukan suatu kegiatan dan penyempurnaan sesuai tanggung jawab dengan hasil yang diharapkan. Kinerja merupakan upaya dari suatu tujuan tergantung pada hasil dari kegiatan yang dicapai. Penelitian ini bertujuan untuk menganalisis Pengaruh kompetensi terhadap kinerja pegawai melalui motivasi kerja sebagai variabel intervening pada Biro Pengadaan Sekretariat Daerah Provinsi Kalimantan Tengah. Metode yang digunakan pada penelitian ini adalah eksplanasi. Data dianalisis menggunakan analisis deskriptif dan analisis statistik inferensial model Structural Equation Modeling (SEM) dengan menggunakan pendekatan Partial Least Square (PLS) serta uji validitas dan reliabilitas. Hasil penelitian menyimpulkan bahwa kompetensi tidak berpengaruh langsung antara terhadap kinerja, kompetensi berpengaruh langsung antara terhadap motivasi, motivasi kerja berpengaruh terhadap kinerja. Variabel motivasi merupakan variable intervening, hubungan antara kompetensi terhadap kinerja.

\section{Kata kunci}

Kompetensi, motivasi kerja dan kinerja 


\section{PENDAHULUAN}

Saat ini Indonesia tengah berupaya keras memacu pertumbuhan ekonomi nasional dan daerah sebagai respons terhadap perekonomian dunia yang mengalami perlambatan. Pelaksanaan pekerjaan-pekerjaan yang berkaitan dengan belanja modal, utamanya dalam pembangunan infrastruktur diharapkan dapat semakin menggerakkan pertumbuhan ekonomi dan meningkatkan perputaran uang secara cepat baik di kota besar maupun di daerah-daerah. Untuk melakukan pelaksanaan kegiatan tersebut, pengadaan barang dan jasa pemerintah merupakan salah satu penggerak penting yang memacu pertumbuhan ekonomi baik di tingkat nasional maupun daerah.

Pengadaan barang dan jasa pemerintah untuk Provinsi Kalimantan Tengah dilakukan oleh Unit Kerja Pengadaan dan Jasa yang bernaung di bawah Biro Pengadaan Barang dan Jasa Sekretariat Daerah Provinsi Kalimantan Tengah. Biro Pengadaan Barang dan Jasa sendiri terbentuk pada tahun 2015 dengan fungsi melakukan proses tender pengadaan barang dan jasa yang pembiayaannya bersumber dari anggaran daerah, anggaran negara, hibah atau dana luar negeri di Provinsi Kalimantan Tengah. Hal yang patut dicermati adalah cita-cita untuk mencapai center of excellence dalam pengelolaan pengadaan barang dan jasa, layanan pengadaan, pembinaan sumber daya manusia dan kelembagaan serta pendampingan, konsultasi dan bimbingan tentu tidak lepas dari peran kompetensi orang-orang yang berada dalam organisasi tersebut agar untuk mencapai kinerja yang ditetapkan. Sejalan dengan cita-cita tersebut, sebagaimana yang telah diwartakan oleh Manurung (2016) pada media elektronik antaranews, pada tahun 2016 Biro Pengadaan Barang dan Jasa Provinsi Kalimantan Tengah secara resmi ditetapkan sebagai program percontohan modernisasi Pengadaan nasional fase II sesuai yang dicanangkan Lembaga Kebijakan Pengadaan Barang/Jasa Pemerintah (LKPP) setelah melalui penandatanganan nota kesepahaman Kepala Daerah dengan LKPP. Namun media yang sama melaporkan pula pada tahun 2018, Biro Pengadaan Barang dan Jasa baru menyelesaikan 270 paket melalui proses tender dari total 571 paket diusulkan, sehingga persentase jumlah paket yang telah dirampungkan tak sebanding dengan serapan anggaran triwulan I tahun 2018 yang hanya menyentuh sekitar 9,37 persen. Hal tersebut justru sangat kontradiktif dengan penetapan Biro Pengadaan Barang dan Jasa Provinsi Kalimantan Tengah sebagai program percontohan pada 2 tahun sebelumnya sementara pada awal triwulan I tahun 2018, kinerja dari Biro Pengadaan Barang dan Jasa tidak mencapai sasaran penyerapan yang telah ditetapkan. Padahal kesuksesan suatu organisasi terutama dalam lingkup Pemerintahan sangat ditentukan oleh kinerja yang dimaknai menjadi pencapaian atau apa yang dicapai.

Kinerja merupakan standar ukuran tertentu untuk mengetahui keberhasilan dan prestasi seseorang atau kelompok. Namun demi mencapai kinerja yang ditetapkan tidak terlepas dari faktor kompetensi pegawai yang berada pada organisasi unit kerjanya. Hal tersebut sesuai dengan pernyataan Douglas (1996) yang menyebutkan bahwa kinerja adalah optimalisasi hasil yang dicapai dengan menggunakan segala potensi individu dan organisasi. Dalam menilai sebuah kinerja, Nelson (2007) membagi 3 cara penilaian yaitu kinerja individu, kinerja kegiatan, dan kinerja organisasi. Kinerja individu adalah akumulasi hasil kerja berdasarkan kompetensi yang dicapai oleh seseorang. Kinerja kegiatan adalah serangkaian kegiatan mulai dari input, proses, output, outcome, benefit dan impact. Kinerja organisasi merupakan serangkaian kegiatan yang menghasilkan nilai kerja secara kuantitas, kualitas, efesiensi, efektivitas dan loyalitas. Sementara Gibson, Ivancevich dan Donnelly (2005) menyebutkan suatu kinerja dinilai berdasarkan hasil yang dicapai menurut satuan waktu, sehingga menghasilkan sesuatu yang disebut efisiensi kerja.

Kegiatan yang dilakukan secara efesien, merupakan penilaian hasil kerja sesuai dengan kuantitas dan kualitas yang menggunakan waktu kerja patuh pada aturan kerja. Pada sisi lain suatu organisasi membutuhkan target sebagai pencapaian puncaknya, dimana target menurut teori yang dikemukakan Philips (2009) adalah standar batas pencapaian yang diharapkan dari suatu penggunaan kemampuan untuk tujuan sehingga pencapaian hasil yang mencapai atau melampaui suatu target yang ditetapkan merupakan sebuah prestasi.

Teori-teori tersebut memberikan gambaran bahwa kinerja pada intinya menilai suatu pekerjaan berdasarkan hasil kerja, capaian suatu pekerjaan sangat ditentukan oleh pegawai, dalam memperlihatkan wujud kerjanya. Penilaian kinerja merupakan hal yang penting dilakukan dalam melihat hasil pekerjaan, ukuran penilian kinerja berdasarkan asumsi yang digunakan. Sejalan dengan pernyataan Douglas (1996) dan Nelson (2007) terhadap penilaian kinerja individu, kompetensi berperan penting dari keberhasilan sumber daya manusia dalam mewujudkan tujuan organisasi. Kompetensi berasal dari kata competent yang berarti mampu sepadan dengan kata ability atau kemampuan. Individu yang mandiri dalam suatu organisasi selalu menghasilkan orang-orang yang berkompetensi berdasarkan karyanya. Kompetensi menurut McKenna (2004) berkenaan dengan kebutuhan individu dan kebutuhan organisasi. Menurut Donald (dalam Kamidin, 2010) keberhasilan ini sangat dipengaruhi oleh akses pengembangan diri pada dasarnya dapat dilihat dari empat sisi sudut pandang yang terbentuk integrasi meliputi pengetahuan (knowledge), keterampilan (skill), pengalaman kerja (experience) dan sikap (attitude), teori tersebut diperkuat teori aset sebagaimana dikemukakan Beer et al. (1985) yang menjelaskan bahwa setiap individu SDM dinilai memilki aset kompetensi bagi suatu organisasi, yang saling mempengaruhi untuk menghasilkan kinerja.

Selain kompetensi pegawai, faktor motivasi kerja merupakan salah satu faktor yang mempengaruhi kinerja. Motivasi merupakan sebuah dorongan atau keinginan 
yang timbul dari dalam diri masing-masing individu untuk memenuhi sebuah kebutuhan. Abraham Maslow (1954), mengembangkan teori berdasarkan kebutuhan motivasi. mengidentifikasi dan menganalisis lima kebutuhan dasar, keamanan fisiologi, keamanan, harga diri, aktualisasi diri, kelima kebutuhan dapat meningkatkan kinerja individu dan kinerja organisasi secara keseluruhan. Teori kebutuhan Maslow, menghadirkan kerangka kerja motivasi yang dapat diterapkan.

Beberapa riset terdahulu dalam mengekspolarasi hubungan kausalitas antara kompetensi dengan kinerja masih terlihat inkonsisten dalam memberikan bukti temuan. Pada penelitian yang dilakukan oleh Ismail dan Abidin (2010), Sulaiman et al. (2013), Setyaningdiyah et al. (2013), Renyut et al. (2017), Mubarok (2018) dan Mukhtar (2018) membuktikan bukti secara empiris bahwa kompetensi memberikan pengaruh positif dan signifikan terhadap kinerja, namun hasil penelitian oleh Dubey dan Ali (2011) menunjukkan hasil bahwa kompetensi berpengaruh negatif terhadap kinerja pegawai. Mengacu pada hasil empiris dan fenomena serta realitas yang ada dengan beberapa alasan sebagai dasar dalam menjelaskan permasalahan tentang kinerja pegawai, maka penelitian ini dilakukan untuk menguji kembali kompetensi terhadap kinerja pegawai yang terdapat pada penelitian terdahulu dan memasukan variabel motivasi sebagai variabel mediasi dalam hubungan antara kompetensi dengan kinerja. Berdasarkan penjabaran kausalitas tersebut maka kerangka konsep penelitian digambarkan sebagaimana Gambar 1.

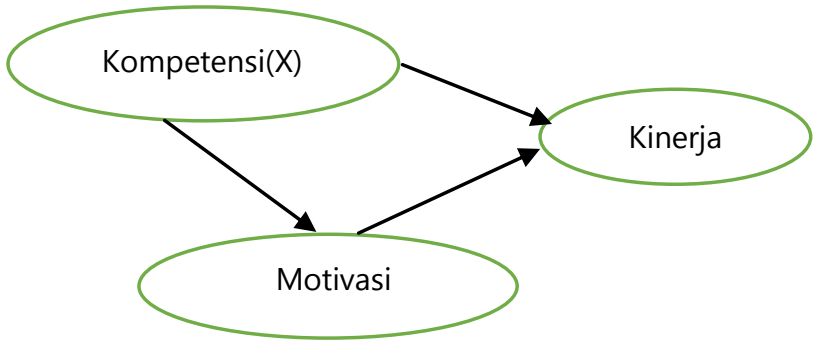

Gambar 1 Kerangka konsep penelitian

Sesuai kerangka konsep penelitian maka hipotesis yang diajukan peneliti adalah:

H.1 : Semakin baik kompetensi, akan meningkatkan motivasi kerja pegawai

H.2 : Semakin baik kompetensi, akan meningkatkan kinerja pegawai

H.3 : Semakin baik motivasi, akan meningkatkan kinerja pegawai

H.4 : Semakin baik kompentensi, akan meningkatkan kinerja pegawai yang di mediasi motivasi kerja

\section{METODE}

Penelitian ini dilaksanakan di Kota Palangka Raya Provinsi Kalimantan Tengah. Penelitian ini bertujuan untuk menganalisis pengaruh kompetensi terhadap motivasi dan kinerja pegawai.

Populasi adalah wilayah generalisasi yang terdiri atas subjek/objek Memiliki potensi dan ciri khusus, yang ditetapkan. Populasi dalam penelitian ini, adalah seluruh pegawai pada Biro Pengadaan Sekretariat Daerah Provinsi Kalimantan Tengah yang meliputi pejabat stuktural, pelaksana, pejabat fungsional, dan tenaga kontrak. Yang berjumlah 42 orang.

Sampel adalah merupakan bagian dari populasi. Teknik pengambilan sampel yang digunakan dalam penelitian ini adalah sampling jenuh, yaitu teknik pengambilan sampel apabila semua populasi dipakai sebagai sampel dan dikenal juga dengan istilah sensus (Sugiyono, 2012). Karena jumlah populasinya sedikit, yaitu sebanyak 42 orang, maka diambil semua sebagai sampel.

Penelitian ini menggunakan 3 variabel dengan Kinerja sebagai variabel dependen (Y), Kompetensi sebagai variabel independen (X) dan Motivasi sebagai variabel mediasi atau intervening ( $Z$ ). Masing-masing variabel tersebut diuraikan menjadi beberapa indikator yaitu: a. Variabel Kinerja $(\mathrm{Y})$ terdiri atas:

1. Kuantitas Hasil Kerja (Y.1) adalah prestasi penyelenggaraan sesuatu kinerja seorang pegawai, akan baik bila dia mempunyai standar dan target kerja yang jelas, 2 item pertanyaan terdiri:

a) Pekerjaan mencapai standar kualitas kerja yang telah ditetapkan instansi.

b) Hasil kerja sesuai dengan target yang telah ditetapkan instansi.

2. Kualitas Hasil Kerja (Y.2) adalah kemampuan yang dimiliki untuk menyelesaikan pekerjaan, dan mengorganisasikan pekerjaan dengan baik yang diukur dari 2 item pertanyaan, yaitu:

a) Hasil kerja memenuhi standar kualitas atau mutu yang ditetapkan oleh instansi.

b) Merencanakan pekerjaan dalam bekerja.

3. Keinginan pegawai (Y.3) adalah kehendak dalam melaksanakan pekerjaan yang didasarkan pada harapan, masa depan yang lebih baik yang dicerminkan melalui pengembangan diri pegawai, kesesuaian gaji dan bonus dari instansi. Variabel ini dikur dengan 3 item pertanyaan, yaitu:
a) Pengembangan pegawai.
b) Kesesuaian gaji.
c) Kesesuaian bonus.

b. Variabel Kompetensi $(X)$ terdiri atas:

1. Pengetahuan (X.1), merupakan kemampuan yang dimiliki pegawai untuk mendukung dan melakukan penyelesaian tugas yang menjadi tanggung jawabnya. Indikator ini diukur dengan 3 pernyataan menggunakan skala Likert 5 poin, yaitu:

a) Pendidikan menunjang kemampuan kerja.

b) Selalu mencari referensi yang berkaitan dengan pekerjaan.

c) Mengetahui hal yang dilakukan untuk sukses dalam bekerja. 
2. Keterampilan (X.2), merupakan kemampuan yang dimiliki pegawai sesuai dengan teknis pekerjaan yang dikerjakan, dari 3 item pernyataan digunakan skala Likert 5 poin:
a) Keterampilan yang dimiliki sesuai teknis pekerjaan.
b) Melalui Pelatihan dapat meningkatkan keterampilan terhadap pekerjaan saya.
c) Mampu memberikan umpan balik tentang permasalahan.

3. Pengalaman Kerja (X.3) adalah masa kerja pegawai dalam berkarir, mempunyai Keahlian yang dimiliki pegawai membantu menyelesaikan tugas dengan cepat, terdiri dari 3 item pernyataan digunakan skala Likert 5 poin:

a) Pegawai yang menunjukkan pengalaman kerja, dan keahlian dipromosikan pada jabatan tertentu.

b) Pegawai yang senior lebih berpengalaman, dan mempunyai keahlian dalam bekerja.

c) Pegawai yang mempunyai pengalaman kerja, ditunjang dengan Keahlian yang dimiliki merupakan kebanggaan diri setiap pegawai.

4. Sikap (X.4) adalah perilaku yang ditunjukkan pegawai dalam menyelesaikan pekerjaan, dengan sebaik-baiknya serta berarti memikul resiko, dan keputusan yang diambilnya atau tindakan yang dilakukannya. 3 item pernyataan digunakan skala Likert 5 point:

a) Kejelasan kerja membuat pegawai bekerja profesional.

b) Berdiskusi menambah keprofesionalan pegawai.

c) Aktualisasi pegawai disusun dalam laporan hasil kerja.

c. Variabel Motivasi (Z)

Darmawan (2013) mendefinisikan motivasi sebagai suatu penggerak atau dorongan dalam diri manusia yang dapat menimbulkan, mengarahkan, dan mengorganisasikan tingkah laku dengan unsur-unsur motivasi kerja, yang terdiri atas:

1. Arah perilaku merupakan perilaku yang dipilih seseorang dalam bekerja, diukur melalui:

a) Adanya keinginan untuk menyelesaikan pekerjaan.

b) Ketaatan pada pertaturan.

2. Tingkat usaha, tingkat usaha mengenai seberapa keras usaha seseorang untuk bekerja sesuai dengan perilaku yang telah dipilih, diukur melalui:

a) Keseriusan dalam bekerja.

b) Keinginan untuk menjadi lebih baik dari sebelumnya.

3. Tingkat kegigihan, tingkat kegigihan adalah seberapa keras pegawai akan terus berusaha untuk menjalankan perilaku yang telah dipilih, diukur melalui:

a) Keinginan untuk mengembangkan keahlian dan memajukan instansi.

b. Kegigihan bekerja meski lingkungan kurang mendukung.

Jenis data penelitian ini, merupakan data primer diperoleh dari responden yakni pegawai pada Biro Pengadaan Sekretariat Daerah Provinsi Kalimantan Tengah yang berhubungan dengan penelitian ini. Data primer ini diperoleh dan bersumber dari responden melalui angket, untuk informasi kualitatif sebagian responden dijadikan informan dan dilakukan wawancara terkait variabel yang diteliti.

Metode pengumpulan data dalam penelitian ini, adalah menggunakan survey dengan instrumen penelitian berupa angket yang disebar kepada responden. Dalam pengumpulan angket melalui proses, peneliti dalam mengumpulkan data primer dengan metode survei melalui instrumen penelitian (angket) dan wawancara, meliputi:

1. Angket sebagai instrumen penelitian, berisi beberapa item pernyataan yang disusun berdasarkan hasil kajian teoritis dan empiris, serta informasi yang diperoleh pada Biro Pengadaan Sekretariat Daerah Provinsi Kalimantan Tengah

2. Wawancara dilakukan untuk memenuhi informasi kualitatif dari responden dijadikan informan yang mendalam dari variabel-variabel penelitian dan responden penelitian yang telah ditetapkan sebelumnya.

3. Data yang diperoleh dari hasil distribusi instrumen penelitian, secara keseluruhan selanjutnya diperiksa, ditabulasi, di-screening serta dianalisis untuk menjawab dan membahas masalah yang diteliti dalam penelitian ini.

Uji instrumen penelitian (test of validity) dibagi menjadi uji validitas dan uji reliabilitas. Dalam uji validitas instrumen dalam penelitian dikatakan valid, Yang diukur berdasarkan variabel apa yang di amati dan tepat, Pengujian validasi instrument yaitu $\alpha$ menghitung koefsien korelasi antara skor item dan skor totalnya dalam taraf signifikan 95\% atau $\alpha=0,05$. Instrumen dikatakan valid mempunyai nilai signifikan korelasi $\leq$ dari $95 \%$ atau $\alpha=0,05$. Validasi dengan menggunakan koefisien korelasi product moment criteria, pengujian yang digunakan pada instrumen yang dikatakan valid jika nilai $r \geq 0,30$ (cut of point). Untuk uji reliabilitas dalam penelitian ini, dilakukan pengukuran dengan metode Alpha Cronbach. Nilai batas (cut of point) yang diterima untuk tingkat Alpha Cronbach adalah $\geq 0,60$, walaupun bukan merupakan standar absolute, Instrumen dapat dikatakan mempunyai keandalan yang dapat diterima, jika nilai koefesien reliabilitas yang terukur adalah $\geq 0,60$. Sebuah instrumen dikatakan reliabel, jika dapat digunakan untuk mengukur variabel berulang kali atau yang menghasilkan data yang sama atau hanya sedikit bervariasi. Metode analisis data yang digunakan dalam penelitian ini yaitu analisis deskripsi dan statistika inferensial yaitu Partial Least Square (PLS). 


\section{HASIL}

\subsection{Karakteristik Responden}

Dari 42 orang pegawai pada Biro Pengadaan Barang dan Jasa, dan dijadikan sampel sebanyak 42 orang yang terjaring seperti pada Tabel 1.

Berdasarkan tabel tersebut dapat diketahui bahwa sebagian besar responden penelitian ini berjenis kelamin laki-laki dengan jumlah 33 orang $(78,5 \%)$ dan perempuan 9 orang $(21,5 \%)$. Berdasarkan umur mayoritas responden berusia antara 38-45 tahun dengan jumlah 17 orang (40,5\%), menyusul usia antara 30-37 tahun sebanyak 10 orang $(23,8 \%), 46-55$ tahun 8 orang (19\%), usia antara 22 29 tahun sebanyak 6 orang (14,3\%) dan dan sisanya berusia 55 tahun dan ke atasnya 1 orang (2,4\%). Secara umum responden penelitian ini berumur antara 30-45 tahun (64,3\%). Ditinjau dari kondisi umur responden menunjukkan bahwa sebagian besar para responden berada pada kisaran umur produktif. Artinya para pegawai diharapkan mempunyai kemampuan fisik untuk bekerja dan memiliki potensi berpikir dan bertindak secara efektif dalam bekerja dan menjalankan tugas secara efektif sehingga diharapkan dapat meningkatkan kinerja. Karakteristik responden berdasarkan masa kerja mayoritas antara 1-3 tahun sebanyak 31 orang $(73,8 \%)$ dan untuk masa kerja 4-6 tahun berjumlah 11 orang (26,2\%). Kondisi ini mencerminkan bahwa sebagian besar responden telah memiliki masa kerja antara 1 sampai 3 tahun dapat memberikan angin segar dan perubahan terhadap kinerja sementara yang berada kisaran di atas 3 tahun sehingga diharapkan lebih profesional dan terampil dalam menjalankan tugas. Kemudian karakteristik responden berdasarkan tingkat pendidikan formal yang ditamatkan mayoritas adalah tamatan sarjana 30 orang (71,5\%) menyusul responden yang tingkat pendidikannya tamatan pascasarjana 8 orang (19\%), tamat SMU/Sederajat 3 orang (7,1\%), dan diploma 1 orang (2,4\%).

Berdasarkan tingkat pendidikan, usia, masa kerja yang dimiliki masing-masing responden diharapkan bahwa responden yang terlibat dalam penelitian ini mempunyai tingkat pemahaman dan pengetahuan yang memadai untuk menjawab pernyataan-pernyataan dalam instrumen penelitian. Dengan demikian informasi yang diperoleh peneliti dari responden merupakan informasi yang relevan dengan tujuan penelitian.

\subsection{Uji Validitas Konvergen}

Pengujian validitas konvergen dilakukan dengan melihat nilai AVE variabel penelitian. Nilai AVE disajikan pada tabel dan dari tabel tersebut dapat dilihat bahwa nilai AVE semua variabel dengan indikator reflektif menunjukkan nilai $>0,50$ yang berarti valid konvergen

Tabel 2 Nilai average variance extracted

\begin{tabular}{cc}
\hline Variabel & AVE \\
\hline Motivasi Kerja Pegawai & 0,664 \\
Kinerja Pegawai & 0,726 \\
\hline
\end{tabular}

\subsection{Uji Reliabilitas}

Uji reliabilitas dilakukan untuk membuktikan akurasi, konsistensi dan ketepatan instrumen dalam mengukur konstruk. Untuk mengukur reliabilitas suatu konstruk dengan indikator reflektif dapat dilihat dari nilai cronbach's alpha dan composite reliability. Composite reliability menguji nilai reliabilitas antara indikator dari konstruk yang membentuknya. Tabel 3 menunjukkan nilai cronbach's alpha serta composite reliability dari variabel penelitian dengan indiktor reflektif. Nilai tersebut bernilai $>0,60$ Sesuai dengan rule of thumb maka semua variabel laten

Tabel 1 Karakteristik responden

\begin{tabular}{|c|c|c|c|}
\hline \multicolumn{2}{|c|}{ Karakteristik Responden } & \multirow{2}{*}{$\begin{array}{c}\begin{array}{c}\text { Frekuensi } \\
\text { (orang) }\end{array} \\
33 \\
9\end{array}$} & \multirow{2}{*}{$\begin{array}{c}\text { Persentase } \\
\text { (\%) }\end{array}$} \\
\hline 1. Jenis kelamin & $\begin{array}{l}\text { a. Laki-Laki } \\
\text { b. Perempuan }\end{array}$ & & \\
\hline & Jumlah & 42 & $100 \%$ \\
\hline \multirow[t]{2}{*}{ 2. Umur } & $\begin{array}{l}\text { a. } 22-29 \text { tahun } \\
\text { b. } 30-37 \text { tahun } \\
\text { c. } 38-45 \text { tahun } \\
\text { d. } 46-55 \text { tahun } \\
\text { e. }>55 \text { tahun }\end{array}$ & $\begin{array}{c}6 \\
10 \\
17 \\
8 \\
1\end{array}$ & $\begin{array}{c}14,3 \% \\
23,8 \% \\
40,5 \% \\
19,0 \% \\
2,4 \%\end{array}$ \\
\hline & Jumlah & 42 & $100 \%$ \\
\hline \multirow[t]{2}{*}{ 3. Masa Kerja } & $\begin{array}{l}\text { a. } 1-3 \text { tahun } \\
\text { b. } 4-6 \text { tahun }\end{array}$ & $\begin{array}{l}31 \\
11\end{array}$ & $\begin{array}{l}73,8 \% \\
26,2 \%\end{array}$ \\
\hline & Jumlah & 42 & $100 \%$ \\
\hline \multirow[t]{2}{*}{ 4. Tingkat Pendidikan (tamatan) } & $\begin{array}{l}\text { a. SMU/Sederajat } \\
\text { b. Diploma } \\
\text { c. Sarjana } \\
\text { d. Pascasarjana }\end{array}$ & $\begin{array}{c}3 \\
1 \\
30 \\
8\end{array}$ & $\begin{array}{l}7,1 \% \\
2,4 \% \\
71,5 \% \\
19,0 \%\end{array}$ \\
\hline & Jumlah & 42 & $100 \%$ \\
\hline
\end{tabular}


dengan indikator reflektif memiliki reliabilitas komposit yang baik pada penelitian yang bersifat exploratory research.

Tabel 3 Hasil pengujian reliabilitas instrumen

\begin{tabular}{lcc}
\hline Indikator/variabel & $\begin{array}{c}\text { Cronbach's } \\
\text { Alpha }\end{array}$ & $\begin{array}{c}\text { Composite } \\
\text { reliability }\end{array}$ \\
\hline Kompetensi & 0,841 & 0,892 \\
Motivasi Kerja Pegawai & 0,835 & 0,887 \\
Kinerja Pegawai & 0,909 & 0,930 \\
\hline
\end{tabular}

Dapat dikatakan bahwa seluruh instrumen yang digunakan dalam penelitian ini telah memenuhi kriteria atau layak digunakan dalam pengukuran variabel kompetensi, motivasi pegawai, dan kinerja pegawai.

\subsection{Pengujian Koefisien Jalur Langsung (Mediasi)}

Hasil dari penelitian dapat terlihat pada tabel dimana hasil yang diperoleh terdapat satu hipotesis tidak dapat dibuktikan secara empiris (ditolak) dan dua hipotesis lainnya dapat dibuktikan secara empiris (diterima).

Tabel 4 menunjukkan bahwa analisis terhadap hipotesis penelitian dapat dilakukan. Hasil pengujian hipotesis pengaruh langsung dapat dijelaskan sebagai berikut:

$\mathrm{H} 1$ : Kompetensi berpengaruh terhadap motivasi kerja pegawai

Hasil pengujian pengaruh kompetensi akan meningkatkan motivasi kerja pegawai dapat dibuktikan dengan melihat nilai estimate koefisien jalur sebesar 0,487 dengan nilai titik kritis (t-statistik) sebesar 4,451 (>1,96) atau Pvalue 0,000 lebih kecil dari $\alpha=0,05$ yang berarti signifikan. Hasil pengujian menunjukkan terdapat cukup bukti secara empiris untuk menerima hipotesis yang menyatakan semakin baik kompetensi akan meningkatkan motivasi kerja pegawai.
$\mathrm{H} 2$ : Kompetensi berpengaruh terhadap kinerja pegawai Hasil pengujian pengaruh kompetensi terhadap kinerja pegawai dapat dibuktikan dengan melihat nilai estimate koefisien jalur sebesar 0,204 dengan nilai titik kritis (t-statistik) sebesar $1,490(<1,96)$ dan Pvalue 0,137 lebih besar dari $\alpha=0,05$ yang berarti tidak signifikan. Hasil pengujian menunjukkan tidak terdapat cukup bukti secara empiris untuk menerima hipotesis yang menyatakan semakin baik kompetensi pegawai akan meningkatkan kinerja pegawai

H3 : Motivasi kerja pegawai berpengaruh terhadap kinerja pegawai

Hasil pengujian memperlihatkan bahwa terdapat cukup bukti secara empiris untuk menerima hipotesis ini. Nilai koefisien jalur hubungan antara variabel motivasi pegawai terhadap kinerja pegawai sebesar 0,707 dengan nilai t-statistik 5,597 (>1,96) dan Pvalue sebesar $0,000 \alpha=0,05$ yang berarti signifikan.

\subsection{Pengujian Koefisien Jalur Tidak Langsung (Mediasi)}

Tabel 5 menunjukkan nilai koefisien jalur variabel kompetensi ke kinerja pegawai tidak signifikan. Hasil ini menunjukkan bahwa variabel motivasi kerja pegawai dalam model penelitian ini merupakan variabel mediasi sempurna (complete mediation).

Terhadap pengujian hipotesis pengaruh tidak langsung yang dapat dijelaskan sebagai berikut:

H4: Motivasi memediasi pengaruh antara kompetensi terhadap kinerja pegawai

Hal ini dapat diartikan bahwa hubungan antara kompetensi secara langsung tidak berpengaruh nyata terhadap kinerja, namun melalui mediasi motivasi kerja pegawai secara nyata mampu mempengaruhi kinerja pegawai. Dengan demikian terdapat cukup bukti secara empiris untuk menerima hipotesis ini yang menyatakan bahwa semakin baik kompetensi akan dapat meningkatkan kinerja pegawai jika dimediasi oleh motivasi kerja pegawai.

Tabel 4 Hasil pengujian hipotesis pengaruh langsung

\begin{tabular}{|c|c|c|c|c|c|c|c|}
\hline \multirow{2}{*}{$\begin{array}{l}\text { Hipotesis } \\
\mathrm{H} 1\end{array}$} & \multicolumn{3}{|c|}{ variabel } & \multirow{2}{*}{$\begin{array}{c}\text { Koefisien jalur } \\
0,487\end{array}$} & \multirow{2}{*}{$\begin{array}{c}\text { T statistic } \\
4,451\end{array}$} & \multirow{2}{*}{$\begin{array}{c}\text { P Value*) } \\
0,000\end{array}$} & \multirow{2}{*}{$\begin{array}{c}\text { Keterangan } \\
\text { diterima }\end{array}$} \\
\hline & Kompetensi & $\rightarrow$ & $\begin{array}{l}\text { motivasi kerja } \\
\text { pegawai }\end{array}$ & & & & \\
\hline $\mathrm{H} 2$ & Kompetensi & $\rightarrow$ & Kinerja pegawai & 0,204 & 1,490 & 0,137 & ditolak \\
\hline H3 & $\begin{array}{l}\text { Motivasi kerja } \\
\text { pegawai }\end{array}$ & $\rightarrow$ & Kinerja pegawai & 0,707 & 5,597 & 0,000 & diterima \\
\hline
\end{tabular}

Tabel 5 Hasil pengujian hipotesis pengaruh tidak langsung

\begin{tabular}{cccccccc}
\hline Hipotesis & & \multicolumn{2}{c}{ Variabel } & Koefisien jalur & T statistic & P Value* & Keterangan \\
\hline H4 & Kompetensi & $\rightarrow$ & Kinerja pegawai & 0,344 & 3,465 & 0,001 & diterima \\
\hline
\end{tabular}

*) signifikan pada $\alpha=0,05$ 


\section{PEMBAHASAN}

Pengkajian terhadap kompetensi, motivasi, dan kinerja adalah dalam upaya untuk mengetahui dan mendalami peran kompetensi terhadap kinerja yang dimediasi oleh motivasi kerja. Pembahasan hasil penelitian bertujuan untuk melakukan pengkajian dan pendalaman teori manajemen sumber daya Manunsia pada instansi pemerintah di Kalimantan Tengah dalam kaitannya dengan variabel penelitian guna memotret posisi baik tidaknya atau tinggi rendahnya penilaian para responden terhadap terhadap kompetensi, motivasi, dan kinerja. Pembahasan hasil penelitian ini bertujuan untuk mengkorfimasi hipotesis penelitian yang diajukan dengan kondisi empiris yang ada di lapangan dan berlandaskan pada tujuan penelitian, kesenjangan penelitian terdahulu, hasil analisis data, dasar-dasar teori manajemen daya manusia, dan hasil -hasil penelitian terdahulu, apakah hasil temuan penelitian dapat memperkuat atau menolak teori maupun hasil penelitian sebelumnya dan atau merupakan hasil temuan baru. Pengujian hipotesis pengaruh langsung terdiri atas tiga hipotesis, hasil pengujian hipotesis diperoleh ketiga hipotesis pengaruh langsung tersebut terdapat dua hipotesis berpengaruh positif signifikan (diterima atau didukung oleh fakta empiris) dan 1 hipotesis berpengaruh tidak signifikan. Hasil pengujian hipotesis diperoleh bahwa hubungan variabel kompetensi terhadap kinerja yang dimediasi oleh motivasi menunjukkan bahwa variabel mediasi motivasi merupakan variabel mediasi sempurna (complete mediation).

Model pengukuran mengacu pada masing-masing indikator pengukuran variabel. Penelitian ini menggunakan variabel dengan indicator yang bersifat reflektif, pembahasan mengenai model pengukuran dengan metode PLS akan menggunakan nilai koefisien estimasi outer loading. Nilai outer loading menunjukkan bobot dari setiap indikator sebagai pengukur dari variabel latennya. Pembahasan hipotesis penelitian dan koefisien jalur dibedakan atas pengaruh langsung dan pengaruh variabel mediasi. Berikut akan dipaparkan pembahasan hasil penelitian berdasarkan hubungan variabel yang dibangun dari hipotesis yang diajukan dengan mengaitkan fakta empiris hasil penelitian dengan teori serta kajian hasil penelitian terdahulu.

\subsection{Pengaruh Kompetensi terhadap Motivasi}

Berdasarkan uji t pada Tabel 4 menunjukan bahwa nilai signifikansi pengaruh variabel kompetensi terhadap motivasi pegawai adalah sebesar 0,000 lebih kecil dari 0,05. Maka secara statistik HO ditolak dan HA diterima. Artinya hipotesis pertama dapat dibuktikan kebenaranya dan hipotesis tersebut dapat diterima. Hal ini berarti bahwa Kompetensi secara langsung dan signifikan positif berpengaruh terhadap motivasi pegawai. Meningkatnya nilai kompetensi akan meningkatkan nilai motivasi pegawai.

Pernyatan ini mendukung teori dan penelitian sebelumnya, seperti yang dikemukakan oleh McKenna
(2004) dan Prayitno et al. (2020), bahwa kompetensi berperan penting bagi keberhasilan sumberdaya manusia dalam mewujudkan tujuan organisasi. Menurut Donald (dalam Kamidin, 2010) keberhasilan ini sangat dipengaruhi oleh akses pengembangan diri pada dasarnya dapat dilihat dari empat sisi sudut pandang yang terbentuk integrasi meliputi pengetahuan (knowledge), keterampilan (skill), pengalaman kerja (experience) dan sikap (attitude), teori tersebut diperkuat teori aset yang dikemukakan Beer et al. (1985) menjelaskan bahwa setiap individu SDM dinilai memilki aset kompetensi bagi suatu organisasi, yang saling mempengaruhi untuk menghasilkan kinerja.

Kompetensi adalah suatu proses yang berusaha untuk meningkatkan efektifitas dan kinerja, dengan mengintegrasikan keinginan individu akan pengembangan tujuan organisasi. Pihak Biro Pengadaan Barang dan Jasa Sekretariat Daerah Provinsi Kalimantan Tengah berupaya untuk meningkatkan kompetensi, dengan cara menanamkan perasaan nyaman, keadilan, kebanggaan, kepemilikan, otonomi, demokrasi, tanggung jawab, fleksibilitas, dan kekeluargaan. Kompetensi ini berkaitan dengan potensi yang dimilki individu sumberdaya manusia dalam berperilaku dan bertindak untuk mencapai tujuannya (Walker, 2007). Individu yang mandiri dalam suatu organisasi selalu menghasilkan orang-orang yang berkompetensi berdasarkan karyanya. Dengan terciptanya kompetensi yang optimal di lingkungan Biro Pengadaan Barang dan Jasa Sekretariat Daerah Provinsi Kalimantan Tengah diharapkan dapat meningkatkan produktivitas kerja serta motivasi pegawai atas pemenuhan kebutuhannya.

\subsection{Pengaruh Kompetensi terhadap Kinerja}

Berdasarkan uji t pada Tabel 4 menunjukan bahwa nilai tidak signifikansi pengaruh variabel Kompetensi terhadap kinerja pegawai adalah sebesar 0,137 lebih besar dari 0,05. Maka secara statistik HO diterima dan HA ditolak. Artinya hipotesis kedua tidak dapat dibuktikan kebenarannya dan hipotesis tersebut ditolak. Hal ini berarti bahwa Kompetensi secara langsung tidak berpengaruh terhadap kinerja pegawai. Koefisien menunjukkan arah yang positif, artinya apabila kompetensi ditingkatkan juga akan meningkatkan kinerja pegawai. Hanya pengaruh tersebut tidak signifikan. Hal ini berarti bahwa kompetensi tidak berpengaruh terhadap kinerja pegawai.

Pernyataan ini tidak sejalan dengan teori dan penelitian sebelumnya, pernyataan tersebut diperkuat teori aset yang dikemukakan Beer et al. (1985) menjelaskan bahwa setiap individu SDM dinilai memilki aset kompetensi bagi suatu organisasi, yang saling mempengaruhi untuk menghasilkan kinerja.

Hasil penelitian ini sejalan dengan studi yang dilakukan Dubey dan Ali (2011), tujuan penelitian mengekspolarasi kompetensi hubungan dengan kinerja, temuan penelitian menunjukkan bahwa kompetensi berpengaruh negatif terhadap kinerja pegawai.

Berdasarkan hasil observasi di lapangan hal tersebut dikarenakan responden dalam penelitian ini adalah karena 
tingginya kompetensi yang dimiliki oleh pegawai secara individual, terjadi pemberian pekerjaan dalam menjalankan tugas pokok fungsi antara bidang yang menaungi dengan tugas organisasi dalam melaksanakan pengadaan barang dan jasa secara keseluruhan menyebabkan beban kerja menjadi tidak seimbang dan proporsional serta pelaksanaan pekerjaan yang tidak sesuai prosedur yang ada. Kompetensi tidak hanya terdiri dari pengetahuan, keterampilan, pengalaman dan sikap saja, dalam terdapat aspek penunjang kompetensi yang mesti dimiliki, dijiwai, dan dikuasai oleh segenap pegawai dalam melaksanakan tugas secara profesional yang meliputi penguasaan bidang pekerjaan secara luas dan mendalam, menyusun, melaksanakan dan menyelesaikan suatu pekerjaan serta kemampuan mengembangkan dan menyebarkan inovasi dalam bidangnya. Sehingga indikator pada variabel kompetensi tidak memiliki pengaruh yang signifikan dalam upaya peningkatan kinerja pegawai pada Biro Pengadaan Barang dan Jasa Sekretariat Provinsi Kalimantan Tengah.

\subsection{Pengaruh Motivasi terhadap Kinerja}

Berdasarkan pada Tabel 4 dapat diketahui pula bahwa nilai signifikansi untuk pengaruh variabel motivasi (Z) terhadap kinerja pegawai $(\mathrm{Y})$ adalah sebesar 0,000 lebih kecil dari 0,05. Maka secara statistik $\mathrm{HO}$ ditolak dan HA diterima. Artinya hipotesis ketiga yang menyatakan bahwa: "motivasi pegawai berpengaruh signifikan positif terhadap kinerja pegawai" dapat dibuktikan kebenarannya dan hipotesis tersebut dapat diterima. Hal ini berarti bahwa Motivasi secara langsung dan signifikan berpengaruh terhadap kinerja pegawai. Dan meningkatnya nilai motivasi akan meningkatkan nilai kinerja pegawai.

Orang bekerja pada suatu organisasi disebabkan adanya kebutuhan yang ingin dipenuhi, kebutuhan dasar adalah makan dan minum (kebutuhan primer), untuk itu yang diharapkannya dalam bekerja adalah upah atau gaji untuk memenuhi kebutuhan primer tersebut. Adanya dorongan untuk memenuhi kebutuhan tersebut disebut motivasi.

Hasil pengamatan pada Biro Pengadaan Barang dan Jasa Sekretariat Daerah Provinsi Kalimantan Tengah bahwa untuk meningkatkan kinerja pegawai, dengan meningkatkan arah perilaku, tingkat usaha, dan tingkat kegigihan. Dengan terciptanya motivasi yang optimal di lingkungan Biro Pengadaan Barang dan Jasa Sekretariat Daerah Provinsi Kalimantan Tengah diharapkan dapat meningkatkan produktivitas kerja serta kinerja pegawai dalam menjalankan tugas dan tanggungjawabnya.

\subsection{Pengaruh Kompetensi Terhadap Kinerja melalui Motivasi Kerja.}

Temuan yang berbeda pada penelitian terdahulu tersebut menimbulkan dugaan bahwa terdapat variabel yang memediasi hubungan antara kompetensi terhadap kinerja pegawai. Dugaan yang mendasari bahwa motivasi merupakan pemediasi dari hubungan ini didasarkan pada temuan dari Beer et al. (1985) yang menyatakan bahwa setiap individu sumberdaya manusia dinilai memiliki aset kompetensi bagi suatu organsiasi.

Beberapa riset terdahulu memperlihatkan bukti terhadap adanya pengaruh kompetensi terhadap kinerja pegawai masih terlihat inkonsisten hasil temuannya. Ekspolarasi hubungan kompetensi dengan kinerja oleh Dubey dan Ali (2011) menunjukkan bahwa kompetensi berpengaruh negatif terhadap kinerja pegawai.

Motivasi kerja merupakan pemediasi sempurna (complete atau full mediation) dari hubungan antara kompetensi terhadap kinerja pegawai. Hasil analisis ditemukan bahwa kompetensi terhadap kinerja pegawai, yang di mediasi oleh motivasi kerja diperoleh nilai positif. Hasil ini berarti pengaruh kompetensi secara langsung tidak berpengaruh signifikan terhadap kinerja pegawai, namun melalui mediasi motivasi kerja secara nyata mampu mempengaruhi kinerja pegawai. Dengan demikian pengaruh kompetensi terhadap kinerja pegawai yang dimediasi oleh motivasi kerja adalah signifikan, maka motivasi kerja berfungsi sebagai variabel mediasi sempurna (complete mediation) antara kompetensi terhadap kinerja pegawai. Temuan penelitian ini memberikan bukti aktual bahwa kompetensi mampu meningkatkan motivasi kerja dan melalui motivasi kerja yang tinggi maka kinerja pegawai dapat meningkat.

Temuan penelitian ini mendukung pandangan Kusnanto (2007) dan Poetri et al. (2020) yang menyatakan bahwa motivasi berperan penting untuk mendorong pegawai untuk dapat meningkatkan kinerja. Motivasi merupakan keinginan yang terdapat pada seseorang individu yang merangsangnya untuk melakukan tindakan atau sesuatu yang menjadi dasar atau alasan seseorang berperilaku. Motivasi merupakan dorongan yang timbul pada diri seseorang secara sadar atau tidak sadar untuk melakukan tindakan sesuai tujuan tertentu, sehingga motivasi sangat penting mendorong seseorang untuk bekerja.

\section{KESIMPULAN}

Hasil studi dalam penelitian ini secara keseluruhan dapat disimpulkan bahwa Pengaruh kompetensi terhadap kinerja dengan motivasi kerja karyawan sebagai variabel mediator pada Biro Pengadaan Barang dan Jasa Sekretariat Provinsi Kalimantan Tengah. Kesimpulan tersebut dapat dinyatakan lebih rinci sebagai berikut:

1. Kompetensi berpengaruh signifikan terhadap motivasi kerja pegawai. Kompetensi yang direpleksikan melalui pengetahuan, keterampilan, pengalaman kerja, dan sikap mampu meningkatkan motivasi kerja pegawai.

2. Kompetensi tidak berpengaruh signifikan terhadap kinerja pegawai. Hal ini disebabkan oleh kompetensi yang direpleksikan melalui pengetahuan, keterampilan, pengalaman kerja, dan sikap tidak mampu meningkatkan kinerja pegawai

3. Motivasi kerja berpengaruh signifikan terhadap kinerja 
pegawai. Motivasi kerja secara keseluruhan mampu meningkatkan kinerja pegawai

4. Motivasi kerja merupakan variabel mediasi penuh (full mediation) hubungan antara kompetensi dengan kinerja pegawai. Secara langsung kompetensi tidak berpengaruh terhadap kinerja pegawai, namun melalui motivasi hubungan kedua variabel dapat berpengaruh.

\section{DAFTAR PUSTAKA}

Beer, M., Walton, R.E., Spector, B., Lawrence, P.R. and Mills, D.Q., 1985. Human resource management: a general manager's perspective: text and cases. New York: Free Press; London: Collier Macmillan.

Darmawan, D. H. 2013. Prinsip-prinsip Perilaku Organisasi. Pena Semesta, Surabaya.

Douglas, J., 1996. Building performance and its relevance to facilities management. Facilities, 14, 23-32

Dubey, R. and Ali, S.S., 2011. Study on effect of functional competency on performance of Indian manufacturing sector. International Journal of Engineering Business Management, 3(3), 1-15.

Gibson, J.L., J.M. Ivancevich dan J.H. Donelly. 2005. Organisasi Perilaku, Struktur dan Proses, Jilid 1-8/E. Binarupa Aksara, Jakarta.

Ismail, R. and Zainal Abidin, S., 2010. Impact of workers' competence on their performance in the Malaysian private service sector. Business and Economic Horizons (BEH), 2(1232-2016-101133), 25-36.

Kamidin, M., 2010. Pengaruh kompetensi terhadap prestasi kerja pegawai sekretariat daerah Kabupaten Bantaeng. Jurnal Economic Resources, 11(30), pp.79-91.

Kusnanto, H. 2007. Motivasi dan Kinerja Organisasi. Penerbit Pustakajaya, Jakarta

Manurung, J.W. (2016). ULP Kalteng Resmi Percontohan Modernisasi Pengadaan Nasional. [Online]. Tersedia di: https://kalteng.antaranews.com/berita/252253/ulp- kalteng-resmi-percontohan-modernisasi-pengadaannasional [15 April 2016].

Maslow, A. H., (1954) Motivation and Personality. Harper and Bros., New York.

McKenna, E. 2004, The Essence of Manajemen Sumberdaya Manusia. Penerbit Andi, Yogyakarta.

Mubarok, E.S. and Putra, H., 2018. Employees Performance of Workers Social Security Agency in Banten Province, Indonesia. Journal of Economics and Sustainable Development, 9(4), 129-139.

Mukhtar, A., 2018. The effect of competence and organization culture to work satisfaction and employee performance of Sharia banks in Makassar city. International Journal of Scientific \& Technology Research, 7(10), 1-6.

Nelson, N. 2007. Human Resources Management in Strength Quality Prospective. McGraw Hill, New York.

Philips, D. 2009. The Human Resource Recruitment Organization. CT. JAI Press, Greenwich.

Poetri, R.I., Mantikei, B. and Kristiana, T., 2020. Pengaruh Kualitas Pelayanan dan Motivasi Kerja terhadap Kinerja Melalui Kepuasan Kerja Pegawai Pada Kantor BPPRD Palangka Raya. Journal of Environment and Management, 1(3), 179-186.

Prayitno, J.H., Mawung, A.S. and Syamsudin, A., 2020. Pengaruh Kompetensi, Insentif dan Motivasi terhadap Kinerja Pegawai pada Badan Narkotika Nasional Provinsi Kalimantan Tengah. Journal of Environment and Management, 1(2), 91-102.

Renyut, B.C., H. B. Modding, J. Bima, S. Sukmawati. 2017. The Effect of Organizational Commitment, Competence on Job Satisfaction and Employees Performance in Maluku Governor's Office, IOSR Journal of Business and Management (IOSR-JBM), 19: 18-29.

Sugiyono. 2012. Metode Penelitian Kuantitatif Kualitatif dan $R \& D$. Penerbit Alfabeta, Bandung.

Sulaiman, W.S.W., Almsafir, M.K. and Ahmad, Z.A., 2013. Job performance: Relationship between competency and attitude towards achieving TNB's vision. Journal of Advanced Social Research, 3(1), 1-11. 